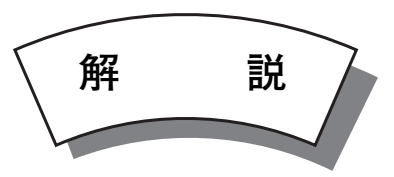

\title{
新機能創製に向けたセラミックスナノクリスタルの高次構造制御 \\ Organic-Ligand-Assisted Hydrothermal Synthesis of Tailor-Made Ceramic Nanocrystals
}

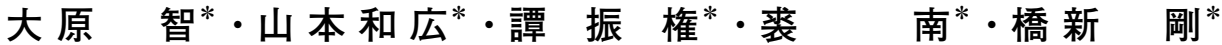 \\ Satoshi OHARA, Kazuhiro YAMAMOTO, Zhenquan TAN, Nan QIU and Takeshi HASHISHIN
}

Key Words: Hydrothermal Synthesis, $\mathrm{CeO}_{2}, \mathrm{TiO}_{2}$, Nanocrystals

\section{1.はじめに}

セラミックスナノ粒子は様々な機能（電気、磁気、光学、 触媒特性等) を有し幅広い分野での応用が期待されている。 また、ナノテクノロジーの進展により同じ物質でもサイズ や形態を高次制御することで、新たな物性や機能が発現す ることが明らかとなってきている。すなわち、これら高次 制御されたナノクリスタルは更なる応用分野の拡大が期待 できる。そのため、材料開発に拈けるナノレベルでの精密 な構造制御、つまり「ナノプロセシング」「ナノファブリ ケーション」の位置付けが極めて重要であり、安心・安全 かつ安価な物質をサブナノオーダーで高次構造制御した機 能性セラミックスナノクリスタルの合成が特に注目されて いる。我々は水熱反応場を利用しセラミックスナノクリス タルを合成しつつ in-situで表面修飾を同時に行う手法につ いて研究開発を進めている。ナノクリスタルの表面に任意 の有機分子を接合することにより、そのサイズや形態の精 緻な制御を目的としている。ここでは、我々が取り組んで いる水熱合成プロセスによるセラミックスナノクリスタル の in-situ での有機表面修飾とそれを活用したナノクリスタ ルの高次構造制御について中心に紹介する。

\section{2. セリアナノクリスタルの構造制御}

近年、超臨界水を反応場としたセラミックスナノ粒子の in-situ 有機表面修飾プロセスが開発されている。筆者の一 人もこの研究に関わったので、まず、このユニークな超臨 界水熱合成プロセスについて述べる。水の物性は臨界点近 傍で大きく変化する。室温での水の誘電率は 78 と極めて高 い值を示し、これが電解質を安定に溶解させうる極性溶媒 としての重要な特性の要因である。しかし、温度の上昇と ともに誘電率は低下し臨界点近傍では $2 \sim 10$ 程度の值とな り、超臨界水では誘電率が非極性溶媒と同等まで低下し水 らしさが失われる。これは超臨界状態の水は油（有機分子） と均一相を形成することを意味する。この特徵に加え、超

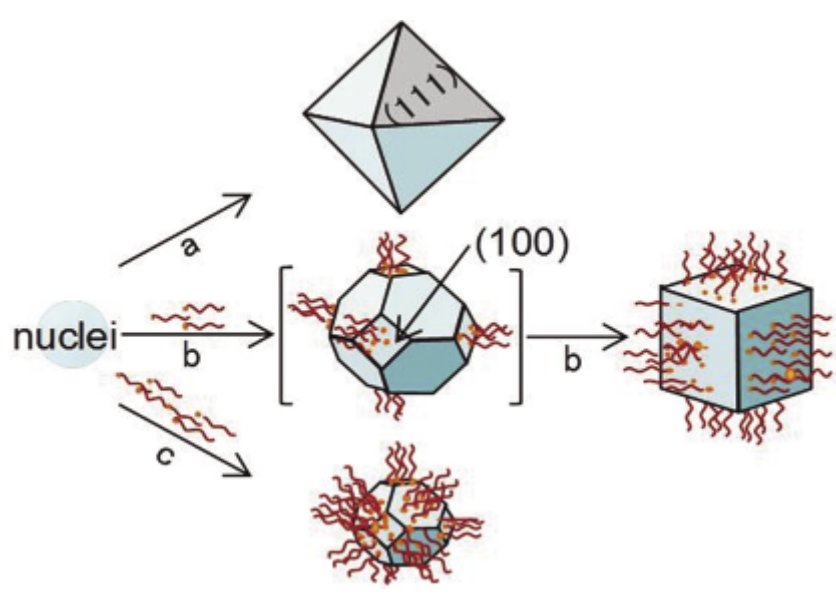

Fig.1 The shape control of $\mathrm{CeO}_{2}$ nanocrystals. (a) A octahedron in the case when no organic-ligand-molecules are used. (b) At a low organic-ligand-molecules to $\mathrm{CeO}_{2}$ precursor ratio, the preferential interaction of the ligand-molecules with the $\mathrm{CeO}_{2}\{001\}$ planes slows the growth of $\{001\}$ faces relative to $\{111\}$ faces, which leads to the formation of nanocubes. (c) At a high organic-ligandmolecules to $\mathrm{CeO}_{2}$ precursor ratio, ligand-molecules block growth on both $\{001\}$ faces and $\{111\}$ faces, which leads to the formation of truncated octahedra crystals.

臨界水中では無触媒下で有機合成反応が進行することをと ントとし、有機分子が表面に接合した無機ナノ粒子が合成 できることが初めて見出された (Fig.1 $)^{1)-8)}$ 。

また、本超臨界水熱合成 in-situ 表面修飾法はセラミッ クスナノ粒子のサイズだけでなく形状制御にも有効な手法 であることが分かってきた $(F i g .1)^{1)}$ 。これは修飾有機分子 の部分的な選択キャッピング効果により、セラミックスナ ノクリスタルの結晶成長が高度に制御されたことに起因す る。Fig.2に表面修飾する有機分子の量を変化させて超臨 界水熱合成したセリア $\left(\mathrm{CeO}_{2}\right)$ ナノ粒子を示す。有機分子を 加えない場合、通常の水熱合成法と同様に 8 面体のナノク リスタルが得られる (Fig.2(a))。一方、有機分子を大量に加

*大阪大学接合科学研究所（† 567-0047 茨木市美穂ヶ丘11-1）

Joining and Welding Research Institute, Osaka University (11-1 Mihogaoka, Ibaraki, Osaka, 567-0047 Japan) 

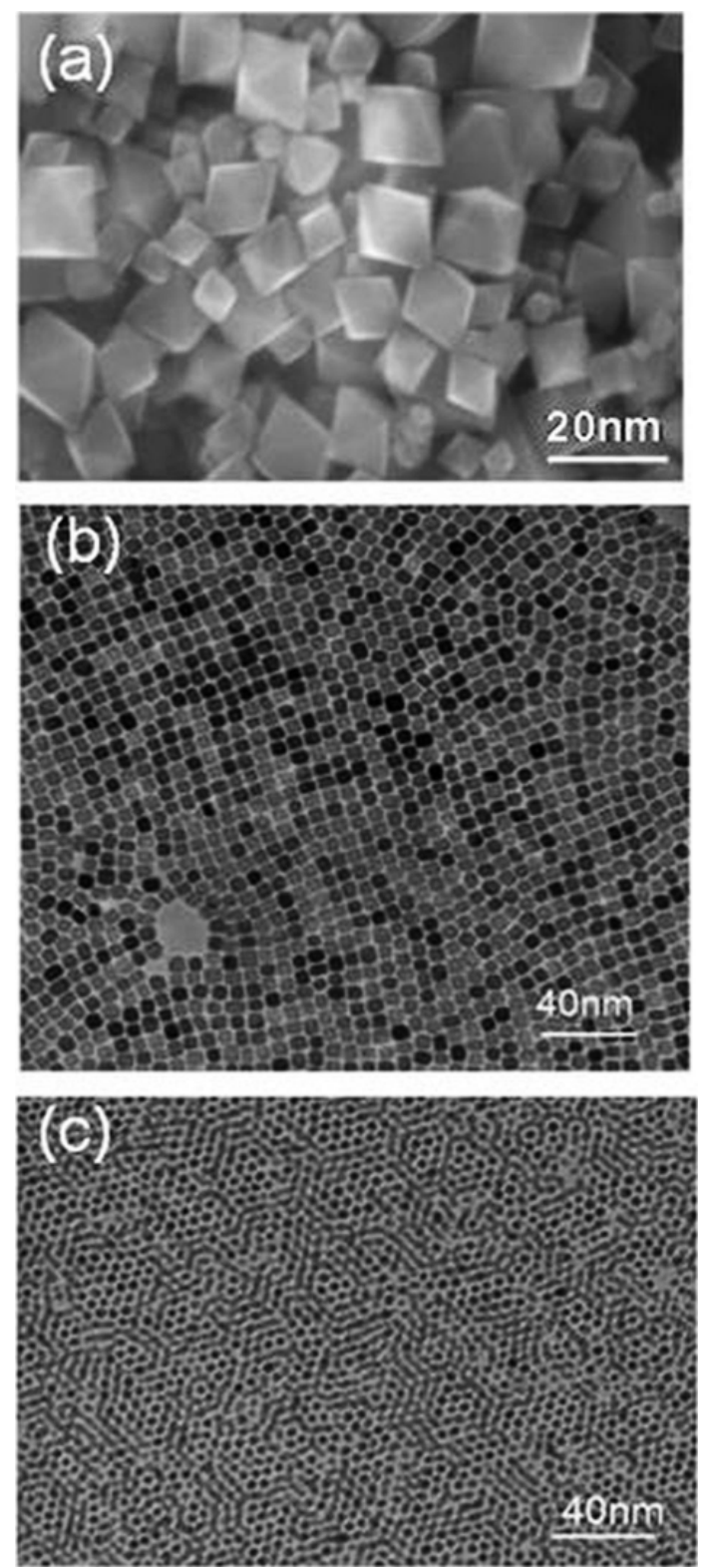

Fig.2 TEM images of octahedra $\mathrm{CeO}_{2}$ nanocrystals (a), $\mathrm{CeO}_{2}$ nanocubes (b), and truncated octahedra $\mathrm{CeO}_{2}$ nanocrystals.

えると核発生したナノ粒子の全ての結晶面に有機分子が接 合し、キャッピング効果により 14 面体のナノクリスタルが 得られる (Fig.2(c))。これに対し適量の有機分子を添加する と活性の高い結晶面にのみ有機分子は接合し、表面修飾に より結晶面の活性は低下し安定化する。そのため、通常の 水熱反応や従来の液相プロセスでは得られない 6 面体のナ ノクリスタル（ナノキューブ）が合成できる (Fig.2(b))。

Fig.3は 6 面体のセリアナノキューブ (Fig.2(b)) に関して、 高分解能の透過型電子顕微鏡 (HR-TEM) を駆使して観察し た写真である。ナノキューブは形状が 6 面体だけではな くその表面に非常にアクティブな (100) 面を有することが
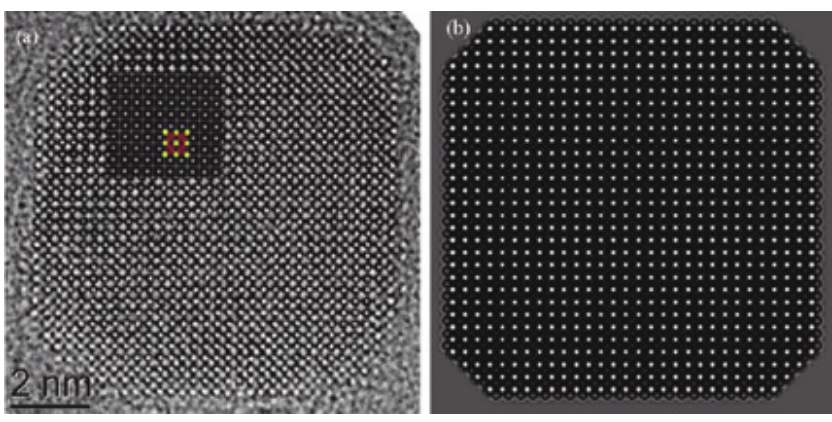

Fig.3 (a) HRTEM image of a $\mathrm{CeO}_{2}$ nanocube viewed in the [001] zone axis. A simulated image is superimposed onto the experimental image, Yellow $=\mathrm{Ce}$, red $=\mathrm{O}$, respectively. (b) A multislice simulation of a $\mathrm{CeO}_{2}$ nanocube of a nanocrystal of similar size and truncation.

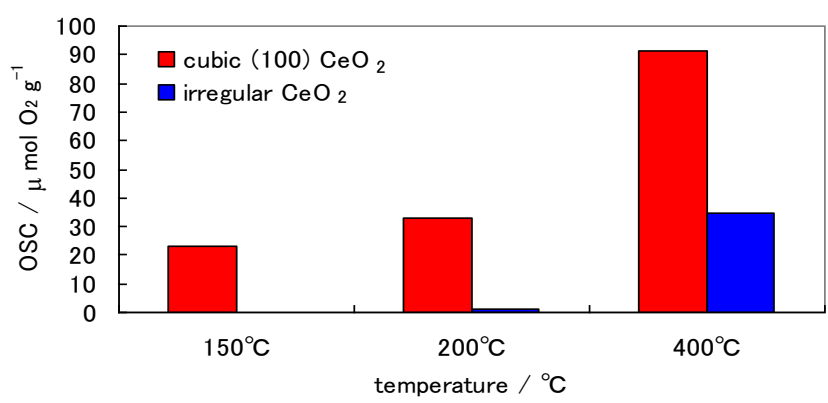

Fig.4 Comparative oxygen storage capacity (OSC) of $\mathrm{CeO}_{2}$ nanocrystals with cubic (100) facets and a sample of irregularly shaped $\mathrm{CeO}_{2}$ nanopowder.

明らかとなった（通常のセリアナノ粒子は 8 面体で表面は (111) 面 $)^{2)}$ 。そのため、通常のセリアナノ粒子を倰駕する触 媒（例えば自動車排気ガス浄化用）機能を有し全くの新材 料のような物性を有することが確認されている(Fig.4)

一方、ナノクリスタルの特異的な機能を十分に発揮する には、それらを凝集することなく所望の媒体中に完全に分 散させることが大前提となる。すなわち、表面制御および 完全分散技術がナノ粒子の本格的実用化を迎える上でブレ イクスルーすべき最重要課題であった。これらの技術発展 はナノクリスタルの応用分野拡大のみならず、ナノ材料科 学に㧍ける学問体系の構築にも大きく貢献するものと考元 られる。これに対し、本超臨界水熱合成されたナノクリス タルは表面修飾された有機分子により溶媒中に完全分散す るため、Fig.2(b)のような大面積で自己組織化した超格子 構造を形成する。これまでに超臨界水熱合成 in-situ 表面修 飾法により、Fig.5のように種々のセラミックスナノクリ スタルが有機溶媒中に完全（透明）分散させることが可能 となり、ナノクリスタルのハンドリング性・分散性が著し 


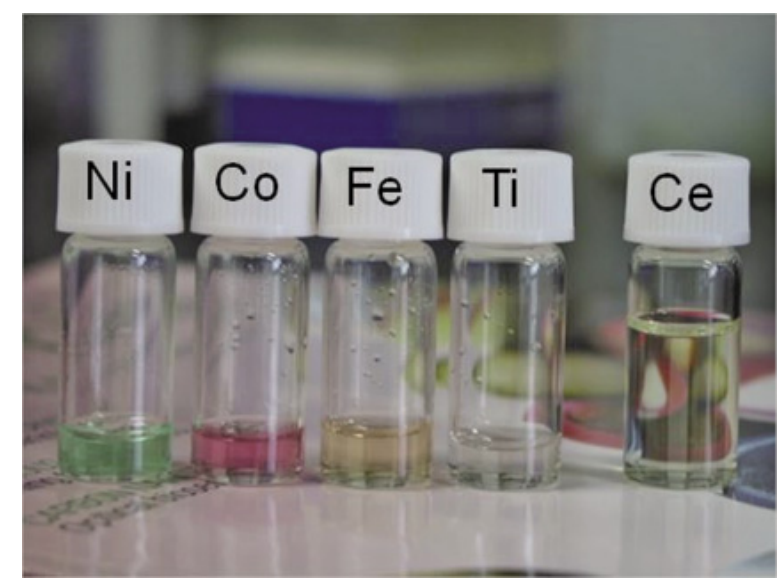

Fig.5 Dispersion behavior of ceramics nanocrystals in solvent.

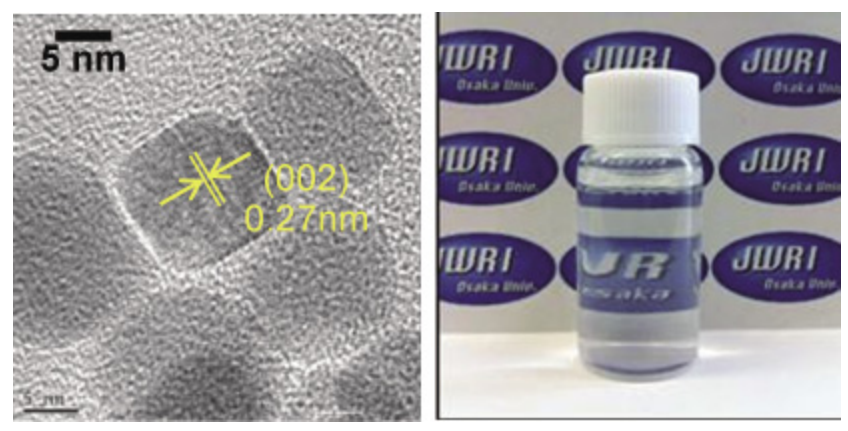

Fig.6 (Left) HR-TEM image of Gd-doped $\mathrm{CeO}_{2}$ (GDC) nanocubes. (Right) Dispersion behavior of GDC nanocubes in water.

く向上できている。

\section{3. 希土類ドープセリアナノクリスタルの構造制御}

超臨界水熱合成 in-situ 表面修飾法のコンセプトを更に発 展させ、我々は現在、水溶性の有機分子やバイオ分子等を 水熱反応場に導入することでセラミックスナノクリスタル の高次構造制御に取り組んでいる。Fig.6に水溶性の 6- ア ミノヘキサン酸をキャッピング剤として水熱合成した希土 類ドープセリアナノキューブ（本研究では Gd-doped $\mathrm{CeO}_{2}$ : GDC）を示す。

先に紹介したセリアナノキューブは、有機配位子として ヘキサン酸やデカン酸といった疎水性有機分子がセリア表 面に接合することによってもたらされる。一方、6-アミノ ヘキサン酸は疎水性の原因となるメチレン鎖 $\left(-\mathrm{CH}_{2}-\right)$ が短 いだけでなく、末端に親水基であるアミノ基 $\left(-\mathrm{NH}_{2}\right)$ を持つ ため、高い親水性を発現する。Fig.7に希土類ドープセリア ナノキューブの表面配位子の分析結果を示す。6-アミノへ キサン酸を添加したセリアナノキューブ、希土類ドープセ リアナノキューブ (Fig.7(b), (c)) にのみ、メチレン鎖とカル

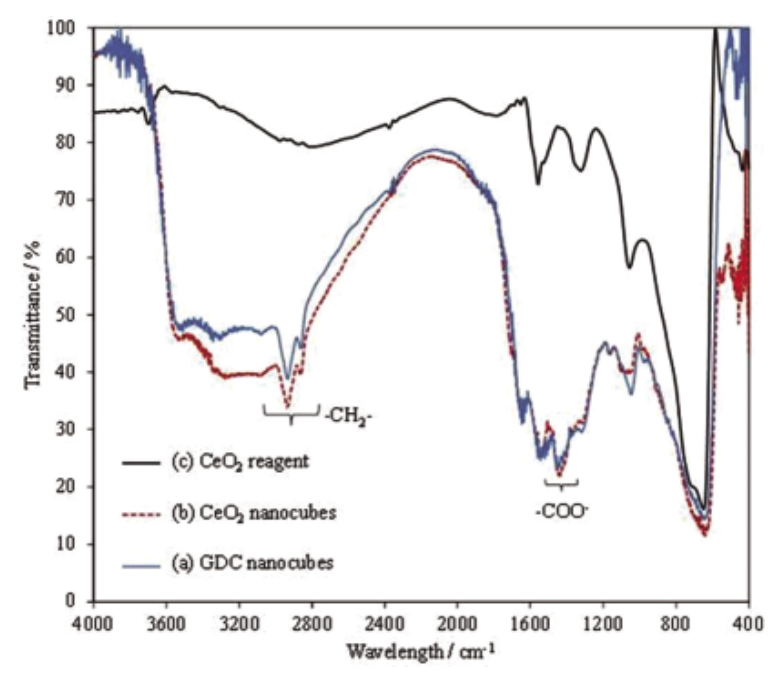

Fig.7 FT-IR spectra of cerium oxide samples: a) $\mathrm{CeO}_{2}$ regent (Wako Pure Chemical); b) $\mathrm{CeO}_{2}$ nanocubes; c) GDC nanocubes.

ボキシル基由来の吸収ピークが確認でき、水溶性アミノ酸 を用いた場合でも、高次形態制御が可能であることを示す。 これによって、新たに水中完全分散が可能なセラミックス ナノクリスタルが得られ、安価で安全な水溶媒を用いた液 相プロセスへの展開が可能となる。以下にその一例を示す。

セリアに希土類をドープすると酸化物イオン導電性が向 上するため、希土類ドープセリアは固体酸化物形燃料電池 (Solid Oxide Fuel Cell：SOFC)の代表的な構成材料である。 燃料電池の中でも SOFC は特に高効率で、長寿命化及び低 コスト化が期待できるため、集中型電源から、分散型、家 庭用、更には自動車用補助電源としての幅広い普及が待望 されている。しかしながら、その実用化には飛躍的な発電 性能の向上が鍵である。これに対し我々は、高活性な (001) 面を有する希土類ドープセリアナノキューブを SOFC の燃 料極に適用し、現状の発電性能を凌駕する超高性能な次世 代の低温作動 SOFC の開発を目指している。

SOFC の燃料極には希土類ドープセリアとニッケル $(\mathrm{Ni})$ を複合化させたサーメットが広く使用されている。合成し たナノキューブは水中に完全分散 (Fig.6) するため、酸化 ニッケルナノ粒子との均一な複合・集積化が可能である。 そこでエアロゾルプロセスによりナノキューブと酸化ニッ ケルナノ粒子とを複合・集積化させた SOFC 燃料極用コン ポジットナノ粒子 (Fig.8) を合成し、電極性能の更なる高性 能化を試みた。その結果、合成したコンポジットナノ粒子 から作製したサーメット燃料極は、世界トップの電極性能 $\left(600^{\circ} \mathrm{C} \text { 程度の低温作動）を有することを実証した (Fig.9 }\right)^{9)}$ 。

\section{4. チタニアナノクリスタルの構造制御}

チタニア $\left(\mathrm{TiO}_{2}\right)$ は光触媒をはじめ種々の機能を有する 機能性セラミックスの代表である。また、チタニアは紫外 


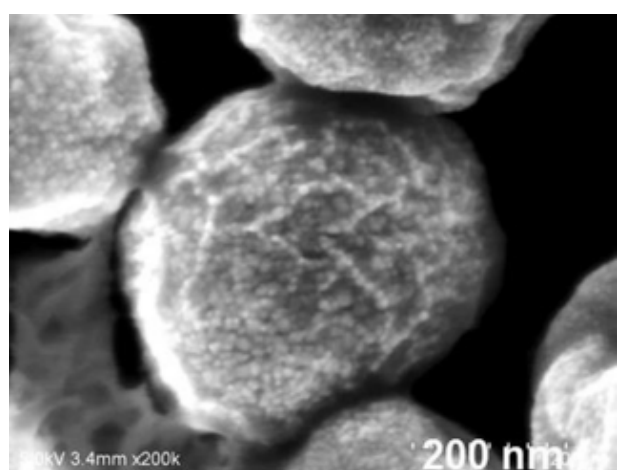

Fig.8 (a) SEM image of NiO-GDC nanocube composite nanoprticles.

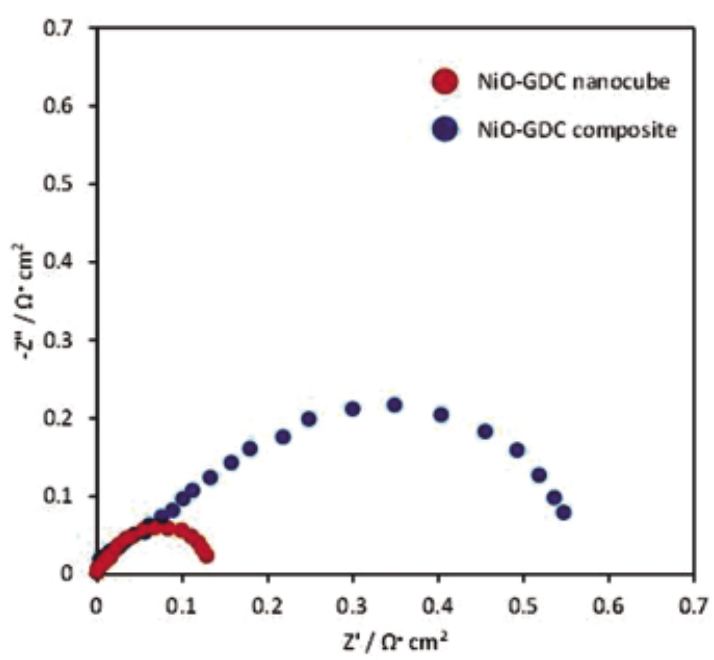

Fig.9 Electrochemical impedance spectroscopy (EIS) spectra of NiOGDC nanocube composite anode and NiO-GDC conventional composite anode.
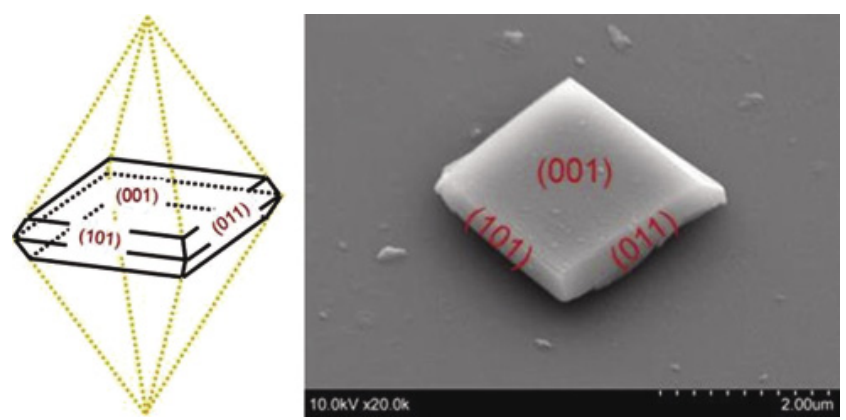

Fig.10 The shape control of $\mathrm{TiO}_{2}$ crystals.

線や超音波等を照射することによりラジカルが発生するた め、DDS 等の医療用材料としても、近年、注目を集めてい

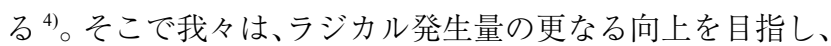
水熱法によるチタニアナノクリスタルのサイズ・形状（結 晶面）等の高次制御技術の確立を試みている。

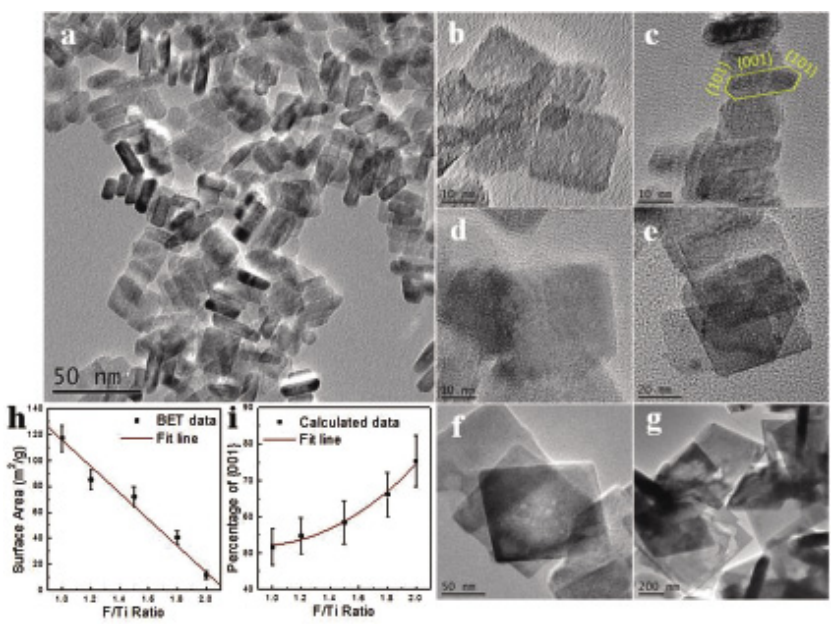

Fig.11 (a) TEM image of $\mathrm{TiO}_{2}$ nanosheets with highly exposed $\{001\}$ facets synthesized with an $\mathrm{F} / \mathrm{Ti}=1.0$. (b \& c) Top and side views, respectively, of the $\{001\}$ surface of $\mathrm{TiO}_{2}$ synthesized with $\mathrm{F} / \mathrm{Ti}=$ 1.0. (d, e, f, g) $\mathrm{TiO}_{2}$ nanosheets synthesized with $\mathrm{F} / \mathrm{Ti}$ molar ratios of $1.2,1.5,1.8$, and 2.0 , respectively. (h \& i) Variation of the specific surface area and percentage of $\{001\}$ surface area with F/ Ti molar ratio, respectively.

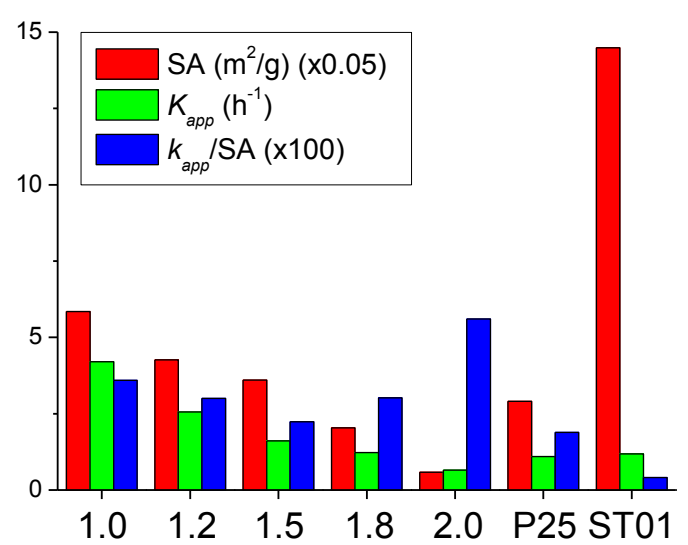

Fig.12 Specific surface area (SA) and pseudo-first-order rate constant $\left(k_{a p p}\right)$ of $\mathrm{TiO}_{2}$ in the photocatalytic degradation of methylene blue.

一般にチタニアクリスタルの結晶面制御は非常に難しく、 そのキャッピング剂としては危険性の高いフッ酸 (HF) が 有効であることが、これまでに報告されているだけであっ た。これに対し我々は、水熱合成反応場にフッ素を含む有 機分子を共存させることにより、チタニアクリスタルの結 晶面制御が可能 (Fig.10) であることを見出し、更にチタニ ア原料と有機分子の比率を最適化することで、20 nm サイ ズの高活性 (001) 面を有するチタニアナノクリスタルの合成 (Fig.11)に成功した。また、有機色素を用いて光触媒機能を 評価した結果、得られた (001) 面チタニアナノクリスタルは 世界最高の性能 (Fig.12) を有することを実証した ${ }^{10)}$ 。 


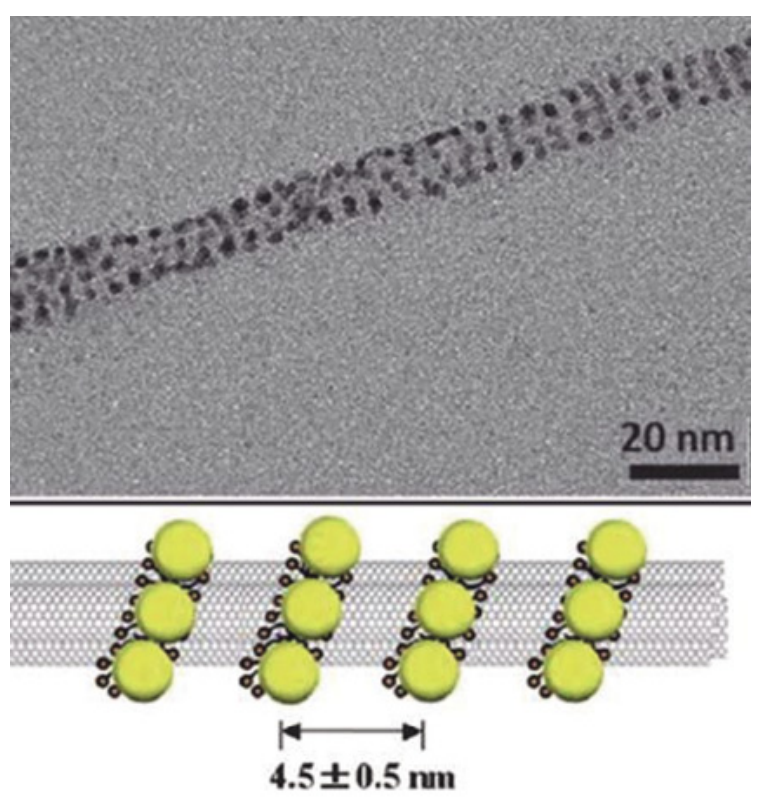

Fig.13 TEM image of Pd nanoparticles selectively deposited on the SDSfunctionalized CNTs.

\section{5. おわりに}

セラミックスナノ粒子の結晶成長を有機分子の部分的選 択キャッピング効果により精密に制御したテーラーメイ ドセラミックスナノクリスタルのプロセスを中心に紹介し た。これらのナノクリスタルは従来の同じ物質を凌駕する 物性や新機能の発現を実現できるため、新材料創製の観点 から極めて興味深い。

今後は分散制御可能な種々の超高機能セラミックスナノ クリスタルをビルディングブロックとして活用し、先進ナ ノコンポジット・ハイブリッド材料が開発されていくこと が大いに期待できる。更にナノ粒子の自己組織化機能やバ イオ分子等の集積化機能を利用することにより無機ナノク リスタルをプログラムドアセンブリーすることが可能とな れば、超高性能な次世代の環境・エネルギー材料の開発に 加え、これまでに全く無い新規な機能を有する光学材料等 の創製に繋がる可能性が非常に高い。その一環として我々 は最近、カーボンナノチューブ $(\mathrm{CNT})$ 上に自己組織的に形 成した界面活性剤（例えば SDS：Sodium Dodecyl Sulfate） をテンプレートした金属ナノ粒子アセンブリーに積極的に 取り組んでいる。その結果、Fig.13に示すようにCNT の 周囲に 3 ナノメートル程度の Pdナノ粒子を螺旋状に坦持
できることを見出した ${ }^{11), 122}$ 。また、ごく最近では同様のテ ンプレート法により CNT 上に数ナノメートルの銀ナノ粒子 をアセンブリーさせることにも成功しており、また、アセ ンブリーさせた銀ナノ粒子から新奇なラマン散乱を確認し ている ${ }^{13)}$ 。このように、無機ナノクリスタルの高次構造制 御とアセンブリーは、これまでのナノテクノロジーのみで は成しえない革新的ナノテクノロジー領域を拓くことがで きる。

\section{謝 辞}

超臨界水を利用した水熱合成プロセスに関する研究は東 北大学多元物質科学研究所・阿尻研究室で行なわれた成果 です。阿尻雅文教授をはじめ関係各位に感謝します。

\section{引用文献}

1) J. Zhang, S. Ohara, M. Umetsu, T. Naka, Y. Hatekeyama and T. Adschiri: , Adv. Mater., 19 (2007) 203-206.

2) K. Kaneko, K. Inoke, B. Freitag, A. B. Hungria, P. A. Midgley, T. W. Hansen, J. Zhang, S. Ohara and T. Adschiri: Nano Lett., 7 (2007) 421-425.

3) D. Rangappa, S. Ohara, T. Naka, A. Kondo, M. Ishii, T. Kobayashi and T. Adschiri: J. Mater. Chem., 17 (2007) 4426-4429.

4) K. Byrappa, S. Ohara and T. Adschiri: Advanced Drug Delivery Reviews, 60 (2008) 299-327.

5) T. Mousavand, T. Naka, K. Sato, S. Ohara, M. Umetsu, S. Takami, T. Nakane, A. Matsushita and T. Adschiri: Phys. Rev. B, 79 (2009) 144411-1-5.

6) D. Rangappa, T. Naka, S. Ohara and T. Adschiri: Crystal Growth \& Design, 10 (2010) 11-15.

7) J. Zhang, H. Kumagai, K. Yamamura, S. Ohara, S. Takami, A. Morikawa, H. Shinjoh, K. Kaneko, T. Adschiri and A. Suda: Nano Lett., 11 (2011) 361-364.

8) J. Zhang, T. Naka, S. Ohara, K. Kaneko, T. Trevethan, A. Shluger and T. Adschiri: Phys. Rev. B, 84 (2011) 045411-1-9.

9) K. Yamamoto, T. Hashishin, M. Matsuda, N. Qiu, Z. Tan and S. Ohara: Nano Energy, 6 (2014) 103-108.

10) Z. Tan, K. Sato, S. Takami, C. Numako, M. Umetsu, K. Soga, M. Nakayama, R. Sasaki, T. Tanaka, C. Ogino, A. Kondo, K. Yamamoto, T. Hashishin and S. Ohara: RSC Advances, 3 (2013) 19268-19271.

11) Z. Tan, H. Abe, M. Naito and S. Ohara: Chem. Comm., 46 (2010) 4363-4365.

12) Z. Tan, H. Abe and S. Ohara: J. Mater. Chem., 21 (2011) 1200812014.

13) J.-C. Valmalette, Z. Tan, H. Abe, and S. Ohara: Scientific Reports, 4 (2014) 5238-1-8. 